\title{
Intellectual property rights and benefit sharing from marine genetic resources in areas beyond national jurisdiction: current discussions and regulatory options
}

\author{
Claudio Chiarolla* \\ Research Fellow, International Biodiversity Governance, Institute for Sustainable Development and \\ International Relations (IDDRI), Paris, France
}

This article considers key aspects of the law of patents, trade secrets, copyrights and databases by explaining why they are relevant to the utilization of marine genetic resources $(M G R s)^{1}$ (and their intangible informational contents) that are sourced from areas beyond national jurisdiction (ABNJ) in the context of the United Nations Convention on the Law of the Sea (UNCLOS). It also provides an assessment of key lessons learned from global regimes on genetic resources in the food and agriculture and health sectors, with a particular focus on intellectual property (IP) management, benefit sharing and the possible use of standard material transfer agreements. It also explains the legal and policy linkage between the proposal to launch the negotiation of a new international instrument under UNCLOS (inter alia to provide an international framework for the sharing of the benefits arising from MGRs in ABNJ) and the possible establishment of a Global Multilateral Benefit-Sharing Mechanism under the Nagoya Protocol. This article concludes that the appropriate management of intellectual property assets that arise from marine scientific research, including bioprospecting, needs to be considered carefully in the context of promoting research and innovation, and their widest possible dissemination for the advancement of science as a global public good.

Keywords: marine genetic resources, biotechnology, bioprospecting, access and benefit sharing (ABS), biodiversity beyond national jurisdiction, gene-based inventions

* The opinions expressed in this article belong solely to the author and do not represent the views or policies of the organization(s) mentioned in this work. The author thanks Mario Chiarolla, Elisabeth Druel, Sophie Arnaud-Haond, Charlotte Salpin, Lyle Glowka and Thomas Greiber for their comments, feedback and fruitful discussions. It is also acknowledged that background research, which has contributed to the sections on UNCLOS and the WHO, was undertaken in preparation for a forthcoming IDDRI Study on the Relations et enjeux des négociations relatives à l'accès aux ressources génétiques et connaissances traditionnelles associées et au partage des avantages issus de leur utilisation dans le contexte de la future entrée en vigueur du Protocole de Nagoya (Paris, 2014 forthcoming) by Claudio Chiarolla.

1. In accordance with the definition provided by the Nagoya Protocol on Access to Genetic Resources and the Fair and the Equitable Sharing of Benefits Arising from their Utilization (ABS) to the Convention on Biological Diversity (CBD) in its Article 2, "utilization of genetic resources' means to 'conduct research and development on the genetic and/or biochemical composition of genetic resources, including through the application of biotechnology [...]'. 


\section{LEGAL AND POLICY BACKGROUND: IP PROTECTION AND MARINE BIOPROSPECTING IN AREAS BEYOND NATIONAL JURISDICTION}

The question of the management and protection of intellectual property (IP) assets arising from marine scientific research, including bioprospecting, and of the relationship between intellectual property rights and benefit sharing from utilization of marine genetic resources and their derivates ${ }^{2}$ are critically important to designing appropriate regulatory mechanisms to improve the governance framework for marine genetic resources (MGRs) in areas beyond national jurisdiction (ABNJ). In the case of privately funded research as well as university research and public-private partnerships, intellectual property (IP) protection and the appropriate management of IP assets can promote research and innovation as well as their wide dissemination. Patents can provide incentives to promote investments in research and development and - through licensing - potential pathways towards technology transfer, product development and commercialization. However, uncertainties about the legal status of materials, which may arise from the presence of multiple and potentially overlapping patent claims ${ }^{3}$ over marine organisms and their separate parts and components may potentially discourage other researchers within the 'technological prospects' covered by such patents. ${ }^{4}$

According to the United Nations Convention on the Law of the Sea (UNCLOS), areas beyond national jurisdiction (ABNJ) include both 'the Area', ${ }^{5}$ common heritage of mankind, and 'the high seas' ${ }^{6}$ In these oceanic regions which do not fall under the jurisdiction of any State, the exploitation of marine biodiversity is very often unregulated and faces several anthropogenic pressures and threats. ${ }^{7}$ At the UN Conference on Sustainable Development ('Rio+20') the international community committed itself 'to address, on an urgent basis, the issue of the conservation and sustainable use of marine biological diversity of areas beyond national jurisdiction, including by taking a decision on the development of an international instrument under [UNCLOS] ${ }^{8}$ at the 69th session of the UNGA in 2015.

Emerging activities like marine bioprospecting were not envisioned at the time UNCLOS - the overarching legal framework for all human activities in oceans and

2. 'Derivative' means 'a naturally occurring biochemical compound resulting from the genetic expression or metabolism of biological or genetic resources, even if it does not contain functional units of heredity', ibid.

3. This phenomenon is known as the 'tragedy of anti-commons', namely, the 'bargaining failures among owners of multiple complementary IP assets', J Hope, 'Open Source Licensing', in A Krattiger, RT Mahoney, L Nelsen et al. (eds), Intellectual Property Management in Health and Agricultural Innovation: A Handbook of Best Practices (MIHR, Oxford, UK and PPRA, Davis, USA 2007).

4. On the concept of technological prospects, see EW Kitch, 'The Nature and Function of the Patent System' (1977) XX(1) Journal of Law and Economics 265-90 (1977).

5. UNCLOS Article 1.1(1) states that the Area is the seabed and ocean floor and subsoil thereof, beyond the limits of national jurisdiction.

6. UNCLOS Article 86 states that the high seas are all parts of the sea that are not included in the exclusive economic zone, in the territorial sea or in international waters of a State, or in the archipelagic waters of an archipelagic State.

7. E Druel, P Ricard, J Rochette and C Martinez, 'Governance of marine biodiversity in areas beyond national jurisdiction at the regional level: filling the gaps and strengthening the framework for action', Studies $N^{\circ} 04 / 2012$, IDDRI (2012) 102p.

8. UNGA Resolution 66/288, 'The future we want', UN doc. A/RES/66/288, of 11 September 2012, paragraph 162. 
seas - was drafted. ${ }^{9}$ While these activities are currently undertaken in accordance with the principle of 'freedom of scientific research' (under UNCLOS Article 87), the sharing of the benefits arising from the utilization of marine genetic resources is unregulated at the global level and their appropriation occurs on a 'first-come, first-served' basis. In particular, no benefit sharing obligations are established by UNCLOS (or any other international instrument) with regard to the utilization of MGRs taken from ABNJ. Historically, and in light of the access and benefits sharing (ABS) standards now enshrined in the UN Convention on Biological Diversity (CBD) and in its Nagoya Protocol, this situation is perceived as being inequitable and unfair especially for counties with no or limited capacity to undertake oceanographic research and marine bioprospecting.

In order to fill this gap, one of the options under consideration is the development of a new international instrument under UNCLOS that would aim to provide an encompassing framework for the effective conservation and sustainable use of marine biodiversity in $\mathrm{ABNJ}$, including provision on the sharing of the benefits arising from the utilization of marine genetic resources. This proposal has gained attention, most notably within the framework of UN General Assembly and its Ad Hoc Open-ended Informal Working Group to study issues relating to the conservation and sustainable use of marine biological diversity in ABNJ (the UN BBNJ Working Group). ${ }^{10}$ At its fifth meeting, States requested that ' $[\ldots]$ the UN Secretary-General [...] convene two intersessional workshops [...]'. ${ }^{11}$ The first intersessional workshop, held in New York on 2-3 May 2013, focused precisely on marine genetic resources. The Terms of Reference provided a mandate to consider, inter alia, intellectual property rights issues, and lessons learned from global and regional regimes on genetic resources, experiences and best practices. The present article builds

9. While there is no legal definition of 'bioprospecting', a working definition of this term may be necessary. The Oxford English Dictionary defines bioprospecting as 'the search for plant and animal species from which medicinal drugs and other commercially valuable compounds can be obtained'. See <http://oxforddictionaries.com/definition/english/bioprospecting $>$. In addition, a study by UNU-IAS highlights that: 'A common distinction is made between scientific research undertaken for noncommercial purpose, also called "pure scientific research", and commerciallyorientated research, also called "applied scientific research". Bioprospecting [...] could be considered as a form applied scientific research'. See S Arico and C Salpin, UNU-IAS Report Bioprospecting of Genetic Resources in the Deep Seabed: Scientific, legal and Policy Aspect (2005) 15. See also C Chiarolla, R Lapeyre and R Pirard, Biodiversity Conservation: How Can the Regulation of Bioprospecting under the Nagoya Protocol Make a Difference? (2013) IDDRI Study $\mathrm{N}^{\circ} 06 / 13$.

10. Established in 2004 by a Resolution of the UN General Assembly, the BBNJ Working Group has already met several times, with the mandate to provide recommendations to the General Assembly on the conservation and sustainable use of marine biodiversity in ABNJ. Most notably, in 2011, it recommended to the General Assembly that it initiate a process with the view ' $[\ldots]$ to ensuring that the legal framework for the conservation and sustainable use of marine biodiversity in areas beyond national jurisdiction effectively addresses those issues by identifying gaps and ways forward, including through the implementation of existing instruments and the possible development of a multilateral agreement under [UNCLOS]'. See A/66/119, Letter dated 30 June 2011 from the Co-Chairs of the Ad-Hoc Open-ended informal Working Group to the President of the General Assembly. See also section 5 of the present article on a 'Global Multilateral Benefit-Sharing Mechanism under the Nagoya Protocol and its relationship with UNCLOS negotiations'.

11. See the Report of the 5th Meeting of the UN BBNJ Working Group, 7-11 May 2012, New York (A/67/95). 
upon and further expands research previously undertaken as a direct contribution to the work of the UN Working Group on these two topics. ${ }^{12}$

\section{OUTLINE}

Issues concerning the protection of MGR-based inventions under patent law are analysed in section 3. Section 4 considers the relationship between patents, trade secrets and the dissemination of information and knowledge arising from marine scientific research, including bioprospecting. While focusing on open access to scientific publications and data, section 5 provides an assessment of selected issues that concern the management of other types of IPRs, namely copyright and proprietary databases, which can play an important role for the generation and dissemination of data, information, knowledge and technologies arising from the utilization of MGRs. It also discusses opportunities and limitations of open source licensing in the field of marine biological innovation. Section 6 provides an assessment of the lessons learned from other global regimes on genetic resources in the food and agriculture and health sectors, by focusing on, inter alia: the relationship between IP protection and benefits sharing; prohibitions and limitations on exclusive right; monitoring and notification requirements; third party transfers; material and information sharing requirements; and the use of material transfer agreements. Section 7 highlights the legal and policy linkages between the proposed option to launch negotiations on a new international instrument under UNCLOS (to provide a framework for the conservation and sustainable use of marine biodiversity in ABNJ, including benefit sharing from MGRs) and the possible establishment of a Global Multilateral Benefit-Sharing Fund under the Nagoya Protocol on ABS. Finally, section 8 provides overarching conclusions and lessons learned from the above analysis.

\section{PATENT-RELATED ISSUES}

\subsection{Patentability of MGR-based inventions}

Biomolecules, DNA constructs and marine micro-organisms can be utilized in industrial processes and can be synthesized and replicated in a lab. In addition, they may be modified by human intervention and take on characteristic that do not exist in nature. When such human interventions result in a new biotechnological invention that involves an inventive step and is capable of industrial application, the invention may qualify for patent protection. ${ }^{13}$

12. C Chiarolla, Intellectual Property Rights, IUCN Information Paper prepared for the UN Intersessional Workshop on Marine Genetic Resources, May 2013, New York, available at: <http://www.un.org/depts/los/biodiversityworkinggroup/documents/IUCN\%20Information\% 20Papers\%20for\%20BBNJ\%20Intersessional\%20Workshop\%20on\%20MGR.pdf> (accessed 25 November 2013) and C Chiarolla, 'Global Regimes on Genetic Resources: the Food and Agriculture, and Health Sectors', presentation given at the international workshop on marine genetic resources convened by the Secretary-General of the United Nations on 3 May 2013 in New York, USA, available at: <http://www.un.org/Depts/los/biodiversityworkinggroup/workshop1_chiarolla.pdf> (accessed 25 November 2013).

13. Emphasis added on the three standard patentability requirements. Gene-based inventions may comprise, inter alia: nucleic acids, nucleotide sequences and their expression products; 
The World Trade Organization's (WTO) Agreement on Trade Related Aspects of Intellectual Property Rights (TRIPs) requires all WTO Member States to provide minimum standards of protection for a wide range of IPRs. ${ }^{14}$ It provides that a patent shall confer on its owner the right to prevent others from making, using, offering for sale, selling or importing the patented product for a period of 20 years or more. In the case of a process patent, the same rights extend at least to the product obtained directly by the patented process. TRIPs Article 27.1 further requires that ' $[. .$.$] patents be available$ and patent rights enjoyable without discrimination as to the place of invention, the field of technology and whether products are imported or locally produced'. Its purpose is to protect right-holders against arbitrary policies that may undermine their rights. Thus, States are not allowed to take measures that would discriminate in the granting of patents, for instance because the disclosed invention belongs to a particular technological domain (e.g. marine biotechnology). The question of whether a WTO Member State would be allowed to take measures that exclude the grant of a patent (or the enjoyment of patent rights) for inventions based on MGRs that are taken from areas beyond national jurisdiction (ABNJ) has not yet arisen. However, such a form of limitation is not expressly prohibited under TRIPs, since Article 27.1 does not refer to the origin of the resources used for the invention but rather the place of the invention itself.

Since their inception in the 1980s, biotechnology patents and their effects on research and innovation are controversial. Certain inventions have been purposely excluded from the scope of patentable subject matter as defined by national patent law. This may vary from one country to another. WTO Member States are allowed to not grant patents for plants, animals and, essentially, the biological processes for their production. ${ }^{15}$ However, micro-organisms and micro-biological or non-biological processes must be protected. ${ }^{16}$ Some countries thus exclude from patentability, inter alia: plants and animals; discoveries of natural substances; and any invention where the prevention of its commercial exploitation is necessary to protect public order, morality or public health. ${ }^{17}$

Nonetheless, patent offices in countries with advanced biotechnology capacity have routinely granted patents for gene-based inventions. ${ }^{18}$ For instance, in the European Union, 'biological material which is isolated from its natural environment or produced

transformed cell lines; proteins; viruses; vectors; methods, technologies and materials for making, using or analysing such materials; and express sequence tags (ESTs). ESTs are smaller segments of complementary DNA that are used as intermediate research tools. OECD, 'Guidelines for the Licensing of Genetic Inventions' (2006) available at: <http://www.oecd.org/sti/biotech/ 36198812.pdf> (accessed 25 November 2013).

14. The TRIPs Agreement entered into effect on 1 January 1995. It incorporates provisions from several international IPR agreements administered by the World Intellectual Property Organization (WIPO). It also introduces a number of new obligations, including in relation to patents and trade secrets. C Chiarolla, Intellectual Property, Agriculture and Global Food Security: The Privatization of Crop Diversity (Edward Elgar, Cheltenham 2011).

15. In accordance with TRIPs Article 27.3(b), countries are free to define subject matter exclusions that are broad enough to avoid the granting of patents on living organisms and on their genetic parts and components, with the exception of micro-organisms.

16. Ibid.

17. WIPO, 'Understanding Industrial Property', at p. 6, available at: <http://www.wipo. int/export/sites/www/freepublications/en/intproperty/895/wipo_pub_895.pdf> (accessed 25 November 2012).

18. As regards MGR, in the case of gene sequences and the isolation of proteins - and in some cases, also micro-organisms occurring in nature - the mere isolation and characterization can be enough to satisfy the criteria for patentability, if significant inventive ingenuity is required to isolate and characterize them. C Salpin and V Germani, 'Patenting of Research Results Related 
by means of technical process may be the subject of an invention even if it previously occurred in nature'. ${ }^{19}$ In the United States, three categories of inventions are non-patentable: laws of nature, natural phenomena, and abstract ideas (based on the 'Product of nature doctrine'). ${ }^{20}$ The boundaries of such doctrine are routinely tested in disputes that concern the patentability of DNA and its alleged positive or stifling effects on biological innovation. ${ }^{21}$ In addition to the United States, Australia, Canada, Indonesia, Japan, Singapore and the 18 Member States of the African Regional

to Genetic Resources from Areas beyond National Jurisdiction: the Crossroads of the Law of the Sea and Intellectual Property Law' (2007) 16 Review of European Community and International Environmental Law 1, 12-23.

19. See Article 3.2 of the Directive 98/44/EC on the Legal Protection of Biotechnological Inventions (the Biotechnology Directive) which is incorporated into the EPC by r $23 \mathrm{~b}$ (1) EPC. OJL 213 of 30.7.1998, at pp. 13-21.

20. 35 USC Section 101 states that: 'Whoever invents or discovers any new and useful process, machinery, manufacture, or composition of matter, or any new and useful process, may obtain a patent therefore, subject to the conditions and requirements of this title'. See JM Conley and R Makowski, 'Back to the Future: Rethinking the Product of Nature Doctrine as a Barrier to Biotechnology Patents' (2003) 85 Journal of the Patent and Trademark Office Society 301.

21. Such boundaries were recently under scrutiny in the test case Association for Molecular Pathology v Myriad Genetics, Inc. This case was heard by the US Supreme Court, which vacated a previous Federal Circuit's decision (July 2011) that upheld the eligibility of Myriad's 'isolated DNA' claims on so-called 'Breast Cancer Susceptibility Gene 1 and 2 (BRCA 1 and 2)'. In accordance with the patent specification, 'isolated DNA' includes not only complementary DNA and other made-made constructs, but also genomic DNA that has been 'separated from other cellular components which naturally accompany a native human sequence' and 'removed from its naturally occurring environment'. See the Amicus Curiae by the United States Government, which rejects the patentability of DNA, at pp. 7-8, available at: <http://www.genomicslawreport.com/wp-content/ uploads/2010/11/Myriad-Amicus-Brief-US-DOJ.pdf>. The Supreme Court also ordered that the case be re-examined by the Federal Circuit in light of its former unanimous decision in Mayo $v$ Prometheus Laboratories, which held that Prometheus' method claims to a diagnostic test for auto-immune diseases did not meet subject matter patentability standards because the former 'effectively claim underlying laws of nature'. See Mayo Collaborative Services v Prometheus Laboratories, Inc., 566 U.S. (2012). Experts noted that establishing '[w]hether a method claim impermissibly preempts a law of nature [in Prometheus] or whether a product claim impermissibly claims a product of nature' [in Myriad] does not necessarily entail the use of the same analytical paradigm. C Brinckerhoff, 'My Myriad Nightmare' (2012) PharmaPatents, posted on 22 March 2012, available at: <http://www.pharmapatentsblog.com/2012/03/22/my-myriad-nightmare/>. The fact that the Supreme Court had ordered the lower court to review the Myriad judgment in light of Prometheus was seen as an indication that it believes the latter provides methodological lessons upon which to draw the definition of un-patentable subject matter. However, on 16 August 2012, the Federal Circuit issued its decision in Association for Molecular Pathology v Myriad Genetics, Inc., which reaffirmed the right to patent the two isolated DNA molecules linked to breast and ovarian cancer, as well as the method to screen for potential cancer therapeutics via change in cell growth rates. It also ruled that method claims for comparing or analysing gene sequences are not patent eligible. See G Stohr and S Decker, 'Biotech Industry at Stake in Human Gene Patent Decision' (12 April 2013) available at: <http://www.bloomberg.com/news/2013-04-12/biotechindustry-at-stake-in-human-gene-patent-decision.html> (accessed 23 April 2013) and T Minssen and RM Schwartz, 'Standing on Shaky Ground: US Patent-eligibility of Isolated DNA and Genetic Diagnostics after AMP v USPTO - Part IV' (2013) 3(2) Queen Mary Journal of Intellectual Property 118-144. Finally, on 13 June 2013, the US Supreme Court reversed the Federal Circuit's decision by holding that 'a naturally occurring DNA segment is a product of nature and not patent eligible merely because it has been isolated, but synthetic complementary DNA ("cDNA") is patent eligible because it is not naturally occurring'. 
Intellectual Property Organization generally allow full patentability of animals, plants and biological processes without particular restrictions. ${ }^{22}$

As regards the implementation of subject matter exclusions, a group of countries including China, India, Malaysia, the Philippines, the Russian Federation, Tunisia, the 16 Member States of the Organisation Africaine de la Propriété Intellectuelle (OAPI), as well as the Member States of the European Patent Organisation (EPO) - provide for a limited subject matter exception that covers plant varieties and/or animal breeds, and essential biological processes. ${ }^{23}$ Finally, countries such as those from the Andean Community of Nations, Brazil and Thailand entirely exclude plants, animals (in whole or any part thereof) and essentially biological processes from patentability.

\subsection{Patents on MGR-based inventions in practice}

Arrieta et al. have analysed a set of patent documents (available as of April 2008), ${ }^{24}$ which discloses '4,928 non-redundant marine gene sequences derived from 558 distinct named marine species'. It also shows an increase in the rate of species appearance in patent documents of 12 per cent per year between 1999 and 2008. Arnaud-Haond et al. have also analysed a dataset comprising patent applications filed through the Patent Cooperation Treaty (PCT) between 1991 and December 2009. ${ }^{25}$ The authors found that a total of 677 claims from the PCT dataset were associated with 8648 sequences belonging to 520 distinct marine species. ${ }^{26}$ More recently, Oldham et al. have 'identified 4,162 marine species in patent data of which 1,464 species appear in patent claims'. ${ }^{27}$ Any comparison of the above studies would be inappropriate due their different methodological assumptions in the selection and assessment of patent data. However, the above figures roughly show that there is a non-negligible number of marine species whose appearance in patent claims suggests their utilization is subject to patent restrictions in various jurisdictions.

22. G Dutfield et al., Exploring the Flexibilities of TRIPS to Promote Biotechnology Capacity Building and Appropriate Technology Transfer (IPDEV 2006).

23. Ibid. However, in the above jurisdictions, patents over gene-based inventions that do not name in the claim a particular variety or breed may be still allowed.

24. JM Arrieta, S Arnaud-Haond and CM Duarte, 'What Lies Underneath: Conserving the Oceans' Genetic Resources' (2010) 107 Proc. Natl. Acad. Sci. U.S.A. 18318. The authors report that data was obtained from patent authorities in various jurisdictions including Europe, Japan, the United States, as well as from The World Intellectual Property Organization (PTC applications).

25. S Arnaud-Haond, JM Arrieta and CM Duarte, 'Marine Biodiversity and Gene Patents' (2011) 331 (6024) Science 1521-2. The WIPO PCT makes it possible to seek patent protection for an invention simultaneously in each of a large number of countries by filing a single 'international' patent application (during the so-called 'international phase') instead of filing several separate national or regional patent applications. Then, the granting of patents remains under the control of national or regional patent offices during the 'national phase'.

26. Although this study provides no information about the status of relevant patent applications once they have entered the national phase, it provides an indication of the growing interest in marine biotechnological applications arising from the utilization of MGRs.

27. P Oldham, S Hall and O Forero, 'Biological Diversity in the Patent System' (2013) 8 PLoS ONE 11: e78737. doi:10.1371/journal.pone.0078737. Relevant Latin species names were identified by using the Ocean Biogeographic Information System (OBIS) Database. The analysis includes the test mining of 11 million patent documents from the United States, the European Patent Convention and the PCT in the period 1976-2010. 
While patent activities that concern MGRs may be even larger than the above estimates suggest, it is important to recognize that the exact geographical origin of these resources (ie within or beyond national jurisdiction) is often unknown and therefore it is difficult to ascertain what the true extent of patenting activity may be in relation to MGRs from areas beyond the limits of jurisdiction. ${ }^{28}$ This is because in most cases the naming of the species of origin of the genetic material used in a biotechnological invention, as well as its geographical origin, is not required by patent law.

Besides, meta-genomics allows determining genes' functions by simply screening a mix of DNA from multiple organisms against a reference library without requiring knowledge of the source organism. ${ }^{29}$ The application of molecular genetics and bioinformatics has transformed MGRs into a promising source of appropriable information. The hereditary information which can be found in DNA, coupled with the identification of genes' functions (e.g. the way in which they code for proteins - a process also known as gene expression), can constitute the basis of patent applications that - if granted - provide monopoly rights on the claimed inventions.

The possibility of claiming molecules and DNA constructs previously existing in nature to replicate the processes they perform in nature may impinge on the ability of others to undertaken research on the claimed MGR. ${ }^{30}$ Unrestricted or facilitated access to basic information and discoveries as well as research results relating to MGRs may be critical for the advancement of science ${ }^{31}$ and by extension for marine scientific research. Thus, the patenting of the results of basic research and, in particular, isolated DNA and bio-molecules that are identical to their natural counterparts, could limit access to materials and research tools. In such cases, patents may impede further innovation. With a view to avoiding this, patent laws normally provide for research exemptions. A research exemption is an exception to the exclusive rights granted by a patent that allows researchers to undertake experiments on the patented invention with a view to discovering unknown effects or making improvements on the invention without the prior consent of the patent-holder. The TRIPs Agreement provides for such exemption. ${ }^{32}$ However, this is of a permissive nature and there

28. M Vierros, C Salpin, C Chiarolla and S Arico, 'Emerging and Unresolved Issues: The Example of Seabed and Open Ocean Genetic Resources in Areas beyond National Jurisdiction', in S Arico (ed), Sustainable Oceans in the Twenty-first Century (UNESCO-Cambridge University Press, Cambridge, UK 2014 forthcoming).

29. G Shimmield, 'Extent and Types of Research, Uses and Applications', IUCN Information Paper, supra $\mathrm{n} 12$.

30. For instance, Correa argues that 'allowing appropriation of $[\ldots]$ materials found in nature through an IP right (even if the patent claimer has done work to isolate them or identify their properties) creates barriers that may negatively affect [...] research'. CM Correa, TRIPS-Related Patent Flexibilities and Food Security: Options for Developing Countries, Policy Guide (QUNO-ICTSD, Geneva 2012).

31. AS Kesselhein and J Avorn, 'University-Based Science and Biotechnology Products: Defining the Boundaries of Intellectual Property' (2005) 293 Journal of the American Medical Association 7, 850-54.

32. However, in accordance with TRIPs Article 30, exceptions to patent rights must meet three cumulative conditions, namely that they: (1) do not unreasonably conflict with the normal exploitation of the patent and (2) do not unreasonably prejudice the legitimate interests of the patent owner, (3) taking account the legitimate interests of third parties. See WTO, Canada-Patent Protection of Pharmaceutical Products, WT/DS114/R, WTO (17 March 2000) and C Chiarolla, supra n 14, at p. 105. 
is no international obligation to include it in national patent law. Therefore, research exemptions can greatly diverge in various countries and they can be construed in narrow terms. ${ }^{33}$

\subsection{Disclosure of the source of MGRs and geo-referencing as good scientific practice}

Geo-referencing of sample collection locations appears to be already standard good scientific practice in marine scientific research (MSR) and bioprospecting. However, it is also true that the metadata containing such important information is often fragmented, ${ }^{34}$ making it difficult to establish whether a given MGR was collected within a national jurisdiction or in $\mathrm{ABNJ} .{ }^{35}$

More routine disclosure of the geographical coordinates of collection locations could provide greater legal certainty for all those concerned with research and development. ${ }^{36}$ Such information should follow samples of the collected material as well as their sequence data throughout the R\&D chain, including specimens held by ex-situ culture collections. This could be done by using a unique identifier number, which should be linked to relevant documentation. ${ }^{37}$ Such information should be readily available at any stage of research, development, pre-commercialization and commercialization. This would also promote synergies with the 2010 Nagoya Protocol on ABS, in particular, with the obligation to monitor and enhance transparency about the utilization of genetic resources under Article 17. Relevant information, including information on the 'source' of marine organisms, which may have been collected within or beyond national jurisdiction, could be disclosed at the checkpoint(s) to be established in accordance with the above article.

On the one hand, if disclosed sample collection locations are within areas beyond national jurisdiction, the benefit of geo-referencing would be to exclude the application of domestic access and benefit-sharing legislation or regulatory requirements of any Party to the Nagoya Protocol. On the other hand, in such situations other (multilateral) benefits sharing obligations might be triggered, notably those which may be considered in the context of the BBNJ Working Group.

33. The US jurisprudence has crafted a common law defence in extremely narrow terms in the wake of the leading case, Madey v Duke University, 64 USPQ2d 1727 (Federal Circuit, 2002). The Court of Appeals for the Federal Circuit held that: 'Regardless of whether a particular institution or entity is engaged in an endeavour for commercial gain, so long as the act is in furtherance of the alleged infringer's legitimate business and is not solely for amusement, to satisfy idle curiosity, or for strictly philosophical inquiry, that act does not qualify for the very narrow and strictly limited experimental use defence. Moreover, the profit or non-profit status of the user is not determinative', SR Eisenberg, 'Patent Swords and Shields' (2003) 299(5609) Science 1018-19.

34. United Nations, Oceans and the Law of the Sea - Report of the Secretary-General, A/62/ 66/Add.2 (10 September 2007).

35. This means that geo-reference and other data concerning collection environments are rarely made available in conjunction with MGR samples and their sequence data. Discerning the exact collection location of an organism that is the object of a patent and later commercial development may require a careful consideration of the scientific literature related to the discovery of that organism to find the geographic coordinates. See Arnaud-Haond et al., supra n 25 and Vierros et al., supra $\mathrm{n} 28$.

36. A Broggiato, Exchange of Information on Research Programs Regarding Marine Biodiversity in Areas beyond National Jurisdiction, IUCN Information Paper, supra n 12.

37. A Broggiato, Global and Regional Regimes, Experiences and Best Practices, IUCN Information Paper, supra n 12. 


\title{
4 PATENTS, TRADE SECRETS AND THE DISSEMINATION OF INFORMATION AND KNOWLEDGE
}

\author{
Under Article 244 of UNCLOS:
}

State and competent international organizations shall [...] make available by publication and dissemination through appropriate channels information on proposed major programs and their objectives as well as knowledge resulting from marine scientific research. For this purpose, States [...] shall actively promote the flow of scientific data and information and the transfer of knowledge resulting from marine scientific research, especially to developing States, as well as the strengthening of the autonomous marine scientific research capabilities of developing States through, inter alia, programs to provide adequate education and training of their technical and scientific personnel.

On the one hand, patent protection may generate tensions with the above Article, because confidentially and non-disclosure of information is required prior to patenting in order to safeguard the novelty of the invention. On the other, patent protection promotes the dissemination of useful technical information (on how to perform the invention) once the patent application (and the disclosure therein) is published. However, nationals in many developing countries have difficulties in benefiting from knowledge on technologies and processes that is disclosed in the patent literature, particularly if such knowledge is only available in the form of publications made by foreign IP offices in foreign languages. ${ }^{38}$ The digitization of documents concerning national IP filings and their dissemination through publicly-available databases could enhance access to knowledge, including in the field of marine biological innovation.

Another common assumption is that in jurisdictions where patents are not available for gene-based inventions (because of subject matter exclusions), a more widespread recourse to secrecy and confidentially is relied upon by commercial developers for protecting their innovations compared to jurisdictions where patent protection is available. However, in current commercial practice, patents and trade secrets are used as complementary means of protection that strengthen each other's exclusivity. Patents usually protect the core invention and their disclosure covers only embryonic or early stage research and development results, 'which are insufficient for commercializing the patented technology, absent access to collateral proprietary knowhow' ${ }^{39}$ Such proprietary know-how, which is often developed after the first filing of the patent application, is protectable as a trade secret in accordance with TRIPs Article $39.2 .^{40}$ It can also be contractually protected under a confidentiality agreement. ${ }^{41}$

The management of IP assets that arise from MSR under a regime of confidentiality or trade secrecy appears to be at odds with the spirit of UNCLOS. This is because UNCLOS Article 244 expressly provides for the publication and dissemination of relevant information and knowledge with a view to promoting openness and transparency of marine

38. D Matthews and C Chiarolla, Literature Review on International Intellectual Property Strategy and Development (London, QMUL \& UK Intellectual Property Office 2009).

39. KF Jorda, 'Trade Secrets and Trade-Secret Licensing' in Intellectual Property Management in Health and Agricultural Innovation (2007), supra $\mathrm{n} 3$.

40. TRIPS Article 39.2 provides for the protection of undisclosed information, including trade secrets or know-how and test data.

41. SP Kowlski and A Krattiger, 'Confidentiality Agreements: A Basis for Partnerships' in Intellectual Property Management in Health and Agricultural Innovation (2007), supra n 3. 
science. For example, the Oceanographic Data Exchange Policy of the Intergovernmental Oceanographic Commission (IOC) implements the principles of Article 244 by stating that: 'Member States shall provide timely, free and unrestricted access to all data, associated metadata and products generated under the auspices of IOC programs' ${ }^{42}$ Furthermore, in the context of technology transfer, Article 267 of UNCLOS provides that: 'States, in promoting cooperation pursuant to article 266 [Promotion of the development and transfer of marine technology], shall have due regard for all legitimate interests including, inter alia, the rights and duties of holders, suppliers and recipients of marine technology'. However, this provision is primarily concerned with the transfer of hard (tangible) technologies and only indirectly with the dissemination of data, information and knowledge related to them.

\section{COPYRIGHT-RELATED ISSUES: OPEN ACCESS TO SCIENTIFIC PUBLICATIONS, OPEN-SOURCE LICENSING AND DATABASE PROTECTION}

There is an increasing need to raise awareness of the opportunities provided by the copyright system to support new models of distributing information and creative content and thereby helping to bridge the digital divide. ${ }^{43}$ Open-access scientific publishing and free and open resources software may contribute to the spread of marine biological innovations and the dissemination of MSR results. Open access to relevant scientific publications, data and software (to analyse this data) could be viewed as an important component of non-monetary benefit-sharing. ${ }^{44}$ However, the moderate optimism, which arises from the new opportunities created by open-source business models in scientific publishing, cannot obscure the reality for developing countries, where researchers and users may not have the same access to the Internet, bandwidth and alternate models for managing and distributing information and creative content, as their counterparts in developed countries. ${ }^{45}$

The recent push towards open access to research in Europe ${ }^{46}$ and in the United States $^{47}$ are a promising development, with positive spill-over effects for all those

42. Resolution IOC-XXII-6 specifies that the term 'Product' shall be understood as 'a valueadded enhancement of data applied to a particular application'. In accordance with UNCLOS Article 249, a limited exception is provided for a coastal State by the Guidelines for the Implementation of Resolution XX-6 of the IOC Assembly Regarding the Deployment of Floats in the High Seas within the Framework of the Argo Programme. Such Guidelines provides that coastal States retain the right to restrict the release of data by the 'Implementer' for a limited period of time if the data is 'of direct significance for the exploration and exploitation of natural resources, whether living or non-living'. This exception to the requirement to make data freely available is designed to protect the rights of the coastal State over their continental shelf and exclusive economic zone (EEZ). Therefore, in no case does it apply to data collected from ABNJ.

43. D Matthews and C Chiarolla, supra $\mathrm{n} 38$.

44. T Greiber, Types of Benefits and Benefit-sharing, IUNC Information Paper, supra n 12.

45. D Matthews and C Chiarolla, supra $\mathrm{n} 38$.

46. D Standeford, 'Changes Coming for Open Access to Research in Europe' [2012] IPW, $<$ http://www.ip-watch.org/2012/04/16/changes-coming-for-open-access-to-research-in-europe/ print/> (accessed 26 November 2013).

47. K Burke, 'Obama Administration Announces New Open Access Policy' [2013] IPW, <http:// www.ip-watch.org/2013/02/26/obama-administration-announces-new-open-access-policy> (accessed 10 March 2013). 
involved in MSR, including bioprospecting. In the United Kingdom, most research funds are allocated under the condition that researchers make their results available in an open-access environment, that is, that they allow unrestricted, online access to research papers free of charge. Furthermore, the UK-based Wellcome Trust's openaccess policy 'requires electronic copies of any research papers that have been accepted in a peer-reviewed journal, and are supported in whole or part by the Trust, to be made available [...] within six months of the journal publishers' official date of final publication'. ${ }^{48}$ Similarly, the United States' Fair Access to Science and Technology Research (FASTR) Act, which was recently under discussion, ${ }^{49}$ proposes to make government agencies design and implement a plan to facilitate public access to federally funded research by requiring researchers '[...] to submit a copy of resulting journal articles to the funding agency, which will then make that research widely available within six months'. Other countries such as Brazil, China and South Africa are leading the field in open access implementation in the developing world. ${ }^{50}$

The journal BioMed Central (BMC) ${ }^{51}$ and the Public Library of Science (PLOS ONE - one of the principal cell biology cancer research journals $)^{52}$ provide good examples of a business model which was successfully adopted for open-access peerreviewed scientific publishing. In this model, publication fees - including those necessary to cover peer review, editing, journal production, and online hosting and archiving are paid by the authors rather than by readers. In addition, the PLOS Global Participation Initiative pricing programme offers to waive or reduce the payment required of authors from Low and Lower Middle Income Countries with the aim of promoting the widest global participation in open-access publishing. Open-access policies also concern digital data that are owned or produced with the support of public bodies. For instance, the European Commission's Open Data package ${ }^{53}$ - in particular, the Commission's updated directive on re-use of public sector information - proposes to make favourable re-use conditions applicable to data held by cultural heritage institutions such as libraries (including university libraries), museums and archives. ${ }^{54}$

In sum, investment incentives arising from traditional copyright approaches are likely to play a relatively limited and decreasing role in promoting the generation of knowledge in the field of marine scientific research. Instead, new open-source and common-pool licensing approaches have emerged in regard to the application and

48. Wellcome Trust, 'Open Access Policy', available at: <http://www.wellcome.ac.uk/About-us/ Policy/Policy-and-position-statements/WTD002766.htm> (accessed 26 November 2013).

49. FASTR, S. 350 in the Senate and H.R. 708 in the House.

50. UNESCO, 'Global Open Access Portal', available at: <http://www.unesco.org/new/en/ communication-and-information/portals-and-platforms/goap/access-by-region/> (accessed 26 November 2013).

51. BMC, <http://www.biomedcentral.com/journals> (accessed 26 November 2013).

52. In 2011, PLOS Biology archived an impact factor of 11.46 with an average IF of 13.6 over the past five years. These results place this journal in the top nine of the cell biology cancer research journals. ScienceTechBlog, <http://sciencetechblog.com/2012/07/23/2011-journalimpact-factors/> (accessed 26 November 2013).

53. European Commission, 'Open Data', <http://ec.europa.eu/information_society/policy/psi/ index_en.htm> (accessed 26 November 2013). The entire package comprises: a Communication on Open Data, including data re-use policy; a proposal to revise the 2003 Directive on re-use of public sector information (Directive 2003/98/EC); and a revision of the Decision governing re-use of the Commission's own information.

54. Ibid. However, bodies of an industrial or commercial character, educational and research establishments, and performing cultural institutions will be exempted. 
dissemination of knowledge and data that arise from MSR and marine bioprospecting. Open-source licensing is a form of management of IP assets, initially developed in the software context, whose objective is to disseminate innovation in a non-proprietary fashion. As such, it is an alternative to 'straightforward publication' strategies that would directly place the innovation in the public domain by foregoing IP protection altogether. ${ }^{55}$ An open-source approach may be preferable to straightforward publication when: (1) the inventor/developer has automatically vested IP rights in an intellectual asset; or (2) defensive disclosure through publication would still expose the author to the risk that others might seek ownership of the technology; or (3) it is preferable to set terms of use that exclude everyone who does not agree to make improvements available under the same liberal terms that apply to the core technology. ${ }^{56}$ In the context or inter-institutional research collaborations and consortium agreements, open-source licensing favours precompetitive collaborations and it is instrumental in 'establishing a robust commons for basic or fundamental technologies whose value is likely to be enhanced by cumulative innovation'. ${ }^{57}$

In the field of bioinformatics, most enabling technologies are developed under open-source terms. ${ }^{58}$ Since 1999 , various open-source initiatives have been launched in the life sciences to promote a more transparent, participative, open and inclusive R\&D model than there would be in a proprietary setting. For instance, the BIOS CAMBIA's Patent Lens aims at allowing community-developed analytical tools, patent landscapes and decision support software to be created and shared. ${ }^{59}$ However, the application of open-source licences to non-software technologies is not something obvious since marine biotechnology, in comparison with software development, is far more technologically diverse and dependent on expensive, time-consuming and complex patents - instead of copyright, which is an automatic and inexpensive form of protection.

Finally, when implementing institutional data-sharing policies, an important IP management issue concerns the appropriate consideration of third parties' IP restrictions that may be carried not only by the data per se, but also by the arrangement of such data (in a database). Dodds et al. explain that a compilation of data or information is copyrightable if they '[...] have been selected, coordinated or arranged in such a way that the resulting work, as a whole, constitutes an original work of authorship' ${ }^{60}$ If more authors have contributed to the compilation, the database may be subject to joint copyright ownership. Although the data or information does not need to be new, the way in which it is elected and arranged must show some degree of originality and creativity for the compilation to be protectable under copyright law. In general, copyright protection does not extend to individual data in a database, and such data may be used once extracted from it. This is why a commercial database normally restricts the right to (re)use and further distribute contents extracted from the database by including restrictive clauses in the licensing agreement.

55. J Hope, supra $\mathrm{n} 3$.

56. Ibid.

57. Ibid.

58. Open Bioinformatics Foundation (OBF), <http://www.open-bio.org/wiki/Main_Page> (accessed 27 November 2013).

59. CAMBIA, 'Patent Lens', available at: <http://www.patentlens.net/daisy/patentlens/patentlens. html> (accessed: 27 November 2013).

60. J Dodds, S Somersalo, SP Kowalski and A Krattiger, 'IP and Information Management: Libraries, Databases, Geographic Information System, and Software', in Intellectual Property Management in Health and Agricultural Innovation (2007) supra n 3. 
Besides copyright protection, the Member States of the European Union are the sole countries that also provide sui generis legal protection for databases. In accordance with the 1996 EU Database Directive, the makers of a database enjoy the right to prevent unauthorized acts of extraction and re-utilization of 'the whole or of a substantial part' of a database content, if it is demonstrated 'that there has been qualitatively and/or quantitatively a substantial investment in either the obtaining, verification or presentation of [such] contents' ${ }^{61}$ Thus, in the case of sui generis rights, there is no requirement for creativity or originality in the way data is selected and arranged, as is the case for copyright. Database protection lasts for 15 years from the date of its creation, with an additional 15 years if substantial changes are made to the content of the database. ${ }^{62}$

In conclusion, the different sui generis and copyright-related cases reviewed in this section have shown that various centrifugal tendencies within the intellectual property system exercise their influence on policies and practices that are directly relevant to the management of marine scientific research and its outputs. Namely, on the one hand, a tendency towards open access to scientific publications and data, and open-source licensing of marine biological innovations and, on the other, a tendency towards strengthened proprietary rights in the legal protection of databases. How to possibly reconcile these different tendencies and management practices, and their implications for benefit sharing, need to be further considered in the context of international negotiations of an UNCLOS implementing agreement on biodiversity in areas beyond national jurisdiction.

\section{LESSONS LEARNED FROM GLOBAL REGIMES ON GENETIC RESOURCES: THE FOOD AND AGRICULTURE AND HEALTH SECTORS}

This section will provide an assessment of the lessons learned from other global regimes on genetic resources in the food and agriculture and health sectors. In order to do this, the key features of the FAO International Treaty on Plant Genetic Resources for Food and Agriculture (ITPGRFA) and the WHO Pandemic Influenza Preparedness Framework for the Sharing of Influenza Viruses and Access to Vaccines and Other Benefits (PIP Framework) will be presented. Their comparative analysis will allow the drawing of key lessons learned on, inter alia: the use of standard material transfer agreements; the relationship between IP protection and benefit sharing; prohibitions and limitations on exclusive rights; monitoring and notification requirements; third party transfers; and material and information-sharing requirements.

\subsection{The FAO International Treaty on Plant Genetic Resources for Food and Agriculture}

The International Treaty on Plant Genetic Resources for Food and Agriculture (PGRFA) of the UN Food and Agriculture Organization (FAO) provides an internationally agreed legally-binding framework for the conservation and sustainable use

61. See Article 7, Directive 96/9/EC of the European Parliament and the Council of 11 March 1996 on the legal protection of databases.

62. However, the Directive only protects the rights of nationals of EU Member States, while nationals of other countries are protected under conditions of reciprocity. J Dodds et al., supra n 60. 
of crop diversity and the fair and equitable sharing of benefits, in harmony with the CBD. Within biodiversity, the International Treaty defines a subset of genetic resources of particular importance for agriculture and food security - i.e. PGRFA - and it limits its scope of application to them. In this respect, the Treaty can be considered as a lex specialis for crop diversity, whereas the CBD provides the general framework for biodiversity.

The International Treaty was created to suit the needs of agriculture and plant breeding. In particular, it establishes a Multilateral System (MLS) of access and benefit sharing (ABS) that consists in pooling selected genetic resources for crops coming from various countries. ${ }^{63}$ These pooled resources are available under the facilitated access mechanism of the MLS only if access is required for the purpose of utilization and conservation for research, breeding and training for food and agriculture. This means that national ABS laws that are consonant with the CBD may apply if recipients intend to make use of PGRFA for other purposes, 'such as chemical, pharmaceutical and/or other non-food/feed uses'. ${ }^{64}$

Materials in the MLS are governed by a set of common rules that States agreed upon in a standard contract called the Standard Material Transfer Agreement (SMTA). Thus, access to PGRFA in the Multilateral System is provided on the basis of the SMTA and hence it does not require ad hoc negotiations between providers and recipients of such materials. This reduces transaction costs as 'access shall be accorded expeditiously, without the need to track individual accessions and free of charge, or, when a fee is charged, it shall not exceed the minimal cost involved'. ${ }^{65}$ Providers of PGRFA do not have the obligation to keep track of all subsequent transfers of PGRFA. However, reporting obligations are included in the SMTA in order to ensure that some benefits flow back to the MLS when a product based on MLS materials is commercialized on the market.

The obligation to share benefits is not in favour of a provider, but of the MLS. Thus, the SMTA provides for a 'Third Party Beneficiary' to be able to initiate dispute settlement, should this become necessary, in order to enforce the beneficial interest of the MLS. ${ }^{66}$ Through reporting obligations, and in conjunction with the obligation to use the SMTA for any subsequent third-party transfer of PGRFA, the SMTA enables following the chain of transfers between individual providers and recipients of PGRFA at reduced costs.

While the International Treaty encourages facilitating access to all PGRFA, only materials that are under 'the management and control of the Contracting Parties and in the public domain' will be included in the MLS. ${ }^{67}$ As regards benefit sharing, it envisages four different tools through which benefits can be shared: the exchange of information; access to and transfer of technology; capacity building; and the sharing of monetary and other benefits from commercialization. ${ }^{68}$ In addition, the Treaty

63. Annex I of the International Treaty lists the 64 crop and forage species that are part of the MLS to ensure worldwide food security. See also Article 10.2.

64. International Treaty, Article 12.3.a.

65. International Treaty, Article 12.3.b.

66. FAO, 'Review of the Implementation and Operation of the Standard Material Agreement' (1-5 June 2009) UN Doc IT/GB-3/09/14, paragraph 12.

67. International Treaty Article 11.2, second sentence and Article 11.3. Thus, not all the PGRFA listed in Annex I are automatically included in the MLS. For example, materials in private collections, if not voluntarily included, are outside the purview of the MLS.

68. On non-monetary benefits see M Schloen, S Louafi and T Dedeurwaerdere, Access and Benefit Sharing for Genetic Resources for Food and Agriculture. Current Use and Exchange Practices, Commonalities, Differences and User Community Needs. Report from a Multi-stakeholder Expert Dialogue (Rome, CGRFA Background Study n. 59, 2011) 17. 
emphasizes that facilitated access to the PGRFA itself constitutes a major benefit of the MLS. ${ }^{69}$

Under the SMTA, recipients are free to transfer received materials to third parties without the need to seek the providers' prior informed consent (PIC). Compulsory benefit sharing of 1.1 per cent of income from seed sales must be paid to the MLS if ${ }^{70}$ the commercialized 'product' incorporates 'the material' received from the MLS, ${ }^{71}$ and such 'product' is not freely available for further research and breeding. The latter requirement entails the existence of a patented product (legal restrictions) ${ }^{72}$ or restrictions deriving from particular technologies, such as Genetic Use Restriction Technologies (GURT), or certain restrictive licensing practices (contractual restrictions). Thus, the existence of patent rights, which restrict access to a product based on PGRFA from the MLS, is a precondition for the sharing of monetary benefits arising from its commercialization. However, this benefit-sharing trigger - based primarily on (patent-related) access restrictions - has proved to be ineffective, as no companies or individual recipients have ever reported to make benefit-sharing payments under the Treaty.

Since the development of a new plant variety may take more than ten years, the SMTA also envisages an alternative payment scheme, which provides that recipients may voluntarily choose to make immediately crop-based payments at the discounted rate of 0.5 per cent of the overall sales of seeds pertaining to the same crop species obtained from the MLS (without any additional legal triggers). ${ }^{73}$

\subsection{WHO Pandemic Influenza Preparedness (PIP) Framework for the Sharing of Influenza Viruses and Access to Vaccines and other Benefits}

Within the World Health Organization, negotiations on ABS for influenza viruses with human pandemic potential and access to affordable diagnostics and treatments, including vaccines, received fresh impetus in 2007 from the refusal of Indonesia to continue sharing virus samples with WHO laboratories for influenza surveillance and response purposes. ${ }^{74}$ This refusal was justified on the ground that an Australian company had

69. International Treaty Article 13.1.

70. SMTA Article 6.7 (Rome, 16 June 2006), accessed 1 June 2012, <ftp://ftp.fao.org/ag/agp/ planttreaty/agreements/smta/SMTAe.pdf > and C Chiarolla, 'Plant Patenting, Benefit-Sharing and the Law Applicable to the FAO Standard Material Transfer Agreement' (2008) 11 The Journal of World Intellectual Property 1-28.

71. In accordance with SMTA Article 2, the definition of 'product' excludes products other than PGRFA as well as other products used as commodities.

72. SMTA Article 6.7 creates a link between monetary benefit sharing and the patenting of biotechnological products and processes. SMTA Article 5.d also provides that intellectual and other property rights must be respected. However, interpretative problems may arise because the Treaty and its SMTA prohibit claims that limit ' $[\ldots]$ facilitated access to the Material [...] or its genetic parts or components, in the form received from the Multilateral System'. $\mathrm{C}$ Chiarolla and S Jungcurt, 'Outstanding Issues on Access and Benefit Sharing under the Multilateral System of the International Treaty' (Zurich, Berne Declaration and Development Fund, Background Study, March 2011) <www.evb.ch/en/p25019093.html> (accessed 12 February 2012).

73. SMTA, Article 6.11.

74. T Greiber and SP Moreno (eds) Explanatory Guide to the Nagoya Protocol on Access and Benefit-sharing (Bonn, IUCN 2012) 41-2. 
filed a patent application for vaccine developed from a virus strain initially provided by Indonesia to the $\mathrm{WHO}$, without its prior informed consent. This alleged violation of the CBD was reinforced by concerns for developing countries' limited opportunities to obtain the vaccine. These concerns arose not only from the expected effects of the patent, but also from the largely insufficient global production capacity and the conclusion of advance purchase agreements by some developed countries. ${ }^{75}$ In response to these criticisms, the World Health Assembly (WHA) decided to develop a novel and fairer virus sharing framework in cases of global pandemic influenza viruses. ${ }^{76}$

The PIP Framework was eventually adopted in 2011 as a non-legally binding international agreement, ${ }^{77}$ which provides for a multilateral benefit-sharing arrangement. ${ }^{78}$ Its objective is to improve pandemic influenza preparedness and response, and strengthen the protection against pandemic influenza by strengthening the WHO global influenza surveillance and response system (WHO GISRS), with the objective of a fair, transparent, equitable, efficient and effective system for: (i) the sharing of $\mathrm{H} 5 \mathrm{~N} 1$ and other influenza viruses with human pandemic potential; and (ii) access to vaccines and sharing of other benefits. ${ }^{79}$ However, its scope does not include seasonal influenza viruses or other non-influenza pathogens or biological substances that may be contained in clinical specimens shared under the PIP Framework. $^{80}$

The PIP Framework envisages the use of two different Standard Material Transfer Agreements (SMTA) for the exchange of virus samples:

- SMTA 1 regulates the exchange of viruses between institutions that operate within the WHO GISRS; ${ }^{81}$

- SMTA 2 is used for exchanging samples between the WHO (on behalf of relevant WHO laboratories) and third parties, which operate outside the WHO GISRS. ${ }^{82}$

75. M Wilke, 'A Healthy Look at the Nagoya Protocol - Implications for Global Health Governance', in E Morgera, M Buck and E Tsioumani (eds), The Nagoya Protocol in Perspective: Implications for International Law and Implementation Challenges (Brill/Martinus Nijhoff, Leiden 2013).

76. WHA Resolution 60.28, of 23 May 2007, Pandemic Influenza Preparedness: Sharing of Influenza Viruses and Access to Vaccines and Other Benefits (Sixtieth World Health Assembly, 2007) Agenda item 12.1.

77. WHA Resolution 64.5, of 24 May 2011, Pandemic Influenza Preparedness: Sharing of Influenza Viruses and Access to Vaccines and Other Benefits (Sixty-fourth World Health Assembly, 2011) Agenda item 13.1.

78. DP Fidler and LO Gostin, 'WHO's Pandemic Influenza Preparedness Framework: A Milestone in Global Governance for Health' (2011) 306(2) JAMA 200, and M Wilke, supra n 75 .

79. WHO PIP Framework, Article 2.

80. Ibid. Article 3.

81. WHO PIP Framework, SMTA 1, Article 1.1 - ie '[...] Influenza laboratories that have been designated or recognized by WHO and have accepted to work under agreed WHO terms of reference'.

82. WHO PIP Framework, SMTA2, Article 1, footnote 1 - ie all entities that receive 'PIP Biological Materials' from the WHO-GISRS, such as influenza vaccine, diagnostic and pharmaceutical manufactures, as well as biotechnology firms, research institutions and academic institutions. 
In particular, SMTA 1 expressly prohibits parties to seek any IPRs on the received materials, ${ }^{83}$ while it does not provide for monetary benefit-sharing obligations. As regards non-monetary benefit sharing, it states that:

The Recipient shall actively seek the participation of scientists [...] from originating laboratories and other authorized laboratories, especially those from developing countries, in scientific projects associated with research on clinical specimens and/or influenza virus from their countries and actively engage them in preparation of manuscripts for presentation and publication.

The Recipient shall appropriately acknowledge in presentation and publications, the contributions of collaborators, including laboratories/countries providing clinical specimens or influenza virus with pandemic potential or reagents, using existing scientific guidelines. ${ }^{84}$

On the contrary, SMTA 2 does not limit the possibility of recipients obtaining IPRs over received materials, while this is balanced with specific compulsory benefit-sharing obligations that are negotiated between the WHO and recipient companies in accordance with a given list of options (see Box I). ${ }^{85}$ To date, GlaxoSmithKline, the University of Florida and the Serum Institute of India have concluded benefit-sharing arrangements with the WHO under SMTA $2 .{ }^{86}$ Voluntary benefit-sharing options are also provided. ${ }^{87}$ Finally, third party transfers of PIP materials are allowed if the prospective recipient has already concluded an SMTA with the WHO and the transfer shall be reported to the latter. ${ }^{88}$

\section{Box I Compulsory benefit-sharing options under SMTA 2}

A For manufactures of vaccines and/or antivirals, the recipient shall commit to at least two of the following options:

A.1. Donate at least $10 \%$ of real time pandemic vaccine production to WHO.

A.2. Reserve at least $10 \%$ of real time pandemic vaccine production at affordable prices to WHO.

A.3. Donate at least $\mathrm{X}$ treatment courses of needed antiviral medicine for the pandemic to WHO.

A.4. Reserve at least $\mathrm{X}$ treatment courses of needed antiviral medicine for the pandemic at affordable prices.

A.5. Grant to manufacturers in developing countries licenses on [MAT] that should be fair and reasonable, including in respect of affordable royalties, taking into account development levels in the country of end use of the products, on technology, knowhow, products and processes for which it holds IPR for the production of (i) influenza vaccines, (ii) adjuvants, (iii) antivirals and/or (iv) diagnostics.

83. WHO Framework, SMTA 1, Article 6.1.

84. Ibid. SMTA 1, Articles 5.2 and 5.3.

85. Ibid. SMTA 2, Article 4.1.1 A and B.

86. WHO website: <http://www.who.int/influenza/pip/benefit_sharing/smta2/en/index.html> (accessed 28 November 2013).

87. WHO Framework, SMTA 2, Article 4.1.1 C.

88. Ibid. SMTA 2, Article 4.4. 
A.6. Grant royalty-free licenses to manufactures in developing countries or grant to WHO royalty-free, non-exclusive licenses on IPR, which can be sublicensed, for the production of pandemic influenza vaccines, adjuvants, antivirals products and diagnostics needed in a pandemic. WHO may sublicense these licenses to manufacturers in developing countries on appropriate terms and conditions and in accordance with sound public health principles.

Where Option 5 or 6 is selected, the Recipient shall regularly provide to WHO information on granted licenses and the status of implementation of licensing agreements. [...]

B Manufacturers of products relevant to pandemic influenza preparedness and response, which are not manufacturing vaccines or antivirals, shall commit to one of the following options: A5, A6, B1, B2, B3 and B4.

B.1. Donate to $\mathrm{WHO}$ at least $\mathrm{X}$ diagnostic kits needed for pandemics.

B.2. Reserve for $\mathrm{WHO}$ at least $\mathrm{X}$ diagnostic kits needed for pandemics, at affordable prices.

B.3. Support, in coordination with WHO, the strengthening of influenza specific laboratory and surveillance capacity in developing countries.

B.4. Support, in coordination with WHO, transfer of technology, knowhow and/or processes for pandemic influenza preparedness and response in developing countries.

Source: WHO Framework, SMTA 2, Article 4.1.1.

Besides the SMTA's obligations, industry's direct financial participation in the global influenza preparedness strategy is required by Articles 6.14.3 and 6.14.4 of the PIP Framework, which state that:

Influenza vaccine, diagnostic and pharmaceutical manufactures, using the WHO GISRS, will make an annual partnership contribution to WHO for improving global pandemic influenza preparedness and response.

$[\ldots]$ the annual contribution shall be equivalent to $50 \%$ of the running costs of the WHO GISRS $^{89}$ [and] will commence in 2012.

The distribution between companies must be based on transparency and equity, and their nature and capacities. Partnership contributions will be used, inter alia, for conducting disease burden studies, strengthening laboratory and surveillance capacity, access and effective deployment of pandemic vaccines and antiviral medicines. The amount paid by companies in 2012 was US $\$ 18$ million, while the WHO is expecting to collect US\$28 million in 2013. Finally, the WHO has almost completed

89. 'The running costs of the GISRS for 2010 were approximately US $\$ 56.5$ million. The running costs of the WHO GISRS are understood to be a reference index for the partnership contribution of 50\%. Such running costs may change over time and the partnership contribution will change accordingly. Such running costs are not to include the partnership contribution themselves [sic].' This footnote appears as footnote 1 in the authentic text of the WHO PIP Framework. 
negotiations with companies, including talks regarding a fixed formula for establishing the level of their respective future contributions toward the WHO PIP Framework. ${ }^{90}$

\subsection{Key lessons learned from the comparative analysis ${ }^{91}$}

An important analogy between a key underpinning of the ITPGRFA - ie the interdependence of states on continuous exchange of plant genetic resources for agricultural uses and a fundamental motivation for improving marine scientific research (MSR) under UNCLOS is the importance of facilitated access to samples and data. However, there are also crucial differences between the two. The MLS covers only 64 species and its monetary benefit-sharing obligations only apply to a single category of 'products' ie PGRFA sold on the market for direct cultivation or resale. By contrast, the scope of an instrument to further regulate marine scientific research in ABNJ could apply to all marine biodiversity in such areas, which encompasses potentially millions of species. The products and processes issued from such research may be extremely heterogeneous and encompass applications across multiple technological domains. Thus, the administration of a large number of transactions through an SMTA-like mechanism for MGRs in ABNJ could prove overwhelmingly burdensome. There is also a trade-off between the possible standardization of benefit-sharing obligations and their triggers in order to reduce transaction costs, and the need to accommodate heterogeneous types of products, processes, applications and benefits derived from MGRs in various sectors.

The WHO PIP Framework is also characterized by a narrow scope of application and targets a homogenous set of applications in the field of influenza vaccine - diagnostic and pharmaceutical production. Furthermore, it relies on the WHO Global Influenza Surveillance and Response System, which includes an elaborated research infrastructure with a clear global public health mandate and a structured policy framework for international cooperation. This has also allowed a differentiation between the rights, duties and obligations of public research institutes (regulated under SMTA 1) and those of other for-profit research entities (regulated under SMTA 2). These peculiar characteristics have made possible the direct contribution and involvement of relevant companies and other stakeholders in the WHO global influenza preparedness strategy, including the negotiation and acceptance of benefit-sharing options. An important lesson to be learned is that the marine scientific research community, including marine biotechnology companies and the private sector, should play a proactive role in future discussions concerning MGRs and benefit sharing at the UN Working Group on BBNJ. ${ }^{92}$

Finally, this comparative analysis suggests considering the following elements as part of the available regulatory options for marine scientific research and benefit sharing from MGRs in ABNJ:

- the need to envisage material and information sharing requirements as a fundamental form of non-monetary benefit sharing;

90. C Saez, 'WHO Fine-Tuning Pandemic Flu Preparedness Strategy, Use of Industry Contributions' (2013), IPW, <http://www.ip-watch.org/2013/10/11/who-fine-tuning-pandemicflu-preparedness-strategy-use-of-industry-contributions/> (accessed 28 November 2013).

91. See also A Broggiato, S Arnaud-Haond, C Chiarolla and T Greiber, 'Fair and Equitable Benefit-Sharing from Marine Genetic Resources in Areas beyond National Jurisdiction: Bridging the Gaps between Science and Policy' (2014 forthcoming) Marine Policy.

92. See below section 7 . 
- the relationship between intellectual property rights and benefits sharing as a trigger of users' obligations, including royalty and/or milestone-type payments to a multilateral fund;

- the possible introduction of prohibitions and limitations on obtaining exclusive rights on MGRs from ABNJ (in general or under specific circumstances) in accordance with UNCLOS Article 241;

- the potential use of standard material transfer agreements;

- the regulation of third party transfers, including an obligation to pass on to any subsequent recipient benefit-sharing obligations;

- monitoring mechanisms, notification requirements and dispute settlement procedures and mechanisms;

- the possible role of third party beneficiary's rights, including the right to act on behalf and in the interest of the international community in the context of dispute settlement;

- the possible role of partnership contributions for commercial partners interested in accessing materials and metadata from institutions that belong to public MGR research networks.

\section{THE RELATIONSHIP BETWEEN UNCLOS NEGOTIATIONS AND A GLOBAL MULTILATERAL BENEFIT-SHARING MECHANISM UNDER THE NAGOYA PROTOCOL}

The Nagoya Protocol as such only applies to genetic resources within national jurisdictions. In particular, it was explained elsewhere that: ${ }^{93}$

Both UNCLOS and the CBD provide the legal framework for activities related to marine genetic resources from organisms found within national sovereignty (i.e. in the internal waters, ${ }^{94}$ archipelagic waters ${ }^{95}$ and the territorial sea ${ }^{96}$ ) or jurisdiction (i.e. the exclusive economic zone ${ }^{97}$ and the continental shelf ${ }^{98}$ ). However, divergent views continue to be held regarding the applicability of the CBD to marine genetic resources from areas beyond national jurisdiction. As regards the components of biological diversity, the CBD's scope is set out in Article 4(a), which limits its application to areas within the limits of national jurisdiction. However, [...] the $\mathrm{CBD}$ is also applicable to activities related to biological resources that are sourced from areas beyond national jurisdiction by virtue of Article 4(b). The latter provides that the CBD applies, in the case of processes and activities, regardless of where their effects occur, carried out under

93. Vierros et al., supra n 28. Footnotes n 94 to 99 were included in the original text.

94. The internal waters are the waters situated on the landward side of the baselines (UNCLOS, Article 8). A baseline is a line from which the seaward limits of maritime zones are measured.

95. The archipelagic waters are the waters enclosed by the archipelagic baselines (UNCLOS, Article 49).

96. The breadth of the territorial sea extends up to a limit not exceeding 12 nautical miles, measured from the baselines (UNCLOS, Article 3).

97. The EEZ lies beyond and adjacent to the territorial sea up to 200 miles from the baselines (UNCLOS, Articles 55 and 57).

98. The continental shelf comprises the seabed and subsoil that extend beyond the territorial sea throughout the natural prolongation of its land territory to the outer edge of the continental margin, or to a distance of 200 nautical miles from the baselines where the outer edge of the continental margin does not extend up to that distance (UNCLOS, Article 76). 
a Party's jurisdiction or control, within the area of its national jurisdiction or beyond the limits of national jurisdiction..$^{99}[\ldots]$ Ultimately, the scope of the Nagoya Protocol, as adopted, is limited to genetic resources within national jurisdiction.

On the other hand, UNCLOS is broadly recognized as the overarching framework for all activities in the oceans and seas, including in relation to marine genetic resources. Thus, in order to fill the gap concerning the management of biodiversity in ABNJ, including the fair and equitable sharing of the benefits arising from the utilization of marine genetic resources, one of the options under consideration is the development of a new international instrument under UNCLOS. Such an instrument would aim to provide an encompassing legal framework for the effective conservation and sustainable use of marine biodiversity in ABNJ. This proposal is supported by many States ${ }^{100}$ and it has gained attention, most notably in the UN General Assembly and its Ad Hoc Open-ended Information Working Group on marine biological diversity in ABNJ. ${ }^{101}$

However, in addition to the above negotiations, Article 10 of the Nagoya Protocol also opens the possibility of negotiating a new Global Multilateral Benefit-Sharing Mechanism (GMBSM) regarding genetic resources 'for which it is not possible to grant or obtain prior informed consent' or that 'occur in transboundary situations' ${ }^{102}$ Since the current framework under UNCLOS fails to provide fair and equitable benefit sharing for marine genetic resources in ABNJ (particularly vis-à-vis the ABS standards established by other international instruments), prolonged discussions at the United Nation General Assembly may eventually lead to a strategic forum shifting towards the Convention on Biological Diversity, namely in the context of negotiations on a Global Multilateral Benefit-Sharing Mechanism under Article 10. ${ }^{103}$ Although the

99. For an overview of the debate on the applicability of the CBD, see United Nations 2006, Report of the Ad Hoc Open-ended Informal Working Group to Study Issues relating to the Conservation and Sustainable Use of Marine Biological Diversity beyond Areas of National Jurisdiction, UN Doc. A/61/65.

100. The proponents of a new implementing agreement include: the EU and its Member States, Australia, New Zealand and most countries of the G77. However, while the latter are primarily interested in the issues of MGR governance, benefit sharing and the sustainable use of marine biodiversity, the former have focused their efforts on marine protected areas (MPAs) and environmental impact assessments (EIAs). Therefore, the strategic alliance between countries with different priorities explains why the above cluster of issues are addressed 'together and as a whole' under the same negotiating package at the UN General Assembly.

101. However, some countries, such as the US, Canada, Iceland, Japan, Venezuela, the Russian Federation and the Republic of Korea, are opposed to the proposal since they see no need for such a new instrument. Many of these countries argue that the improvement and implementation of existing frameworks and initiatives (including regional seas conventions, regional fisheries management organization, global sectoral conventions and ad hoc initiatives concerning MSR) are largely sufficient to address marine biodiversity in ABNJ.

102. However, transboundary situations are also addressed under Article 11 of the Nagoya Protocol on 'Transboundary Cooperation'. The fundamental distinction between the cases covered under Article 11 vis-à-vis the cases subjected to Article 10 is that the former focuses on bilateral and regional cooperation, whereby at least one or more cooperating Parties and/or indigenous and local communities may provide their prior informed consent and establish mutually agreed terms. In addition, Article 11 does not offer a ready solution to frequent situations in which genetic resources are shared. On the other hand, Article 10 offers the opportunity to create a multilateral mechanism to complement bilateral and regional approaches to ABS, when the exercise of sovereignty and indigenous and local communities' rights to relevant resources and associated traditional knowledge would not otherwise be possible.

103. Vierros et al., supra n 28. 
abstract possibility that such a future mechanism will include marine genetic resources from $\mathrm{ABNJ}$ may not be ruled out, currently disagreement and confusion are prevalent in international discussions on questions concerning the potential applicability of the latter to resources in marine areas beyond national jurisdiction. ${ }^{104}$

\section{CONCLUSIONS}

The appropriate management of IP assets that arise from marine scientific research, including bioprospecting, needs to be considered carefully in the context of promoting research and innovation and their widest possible dissemination for the benefit of society as a whole. Patents can provide incentives for private sector investment in research and development on marine genetic resources and - through licensing they also promote the transfer and commercialization of relevant marine technologies. However, similarly to the effects that they produce in other biotechnology sectors, the proliferation of patent rights over MGRs may raise the costs of undertaking research with proprietary materials and research tools. As a consequence, newly discovered MGRs may be locked up by patent monopolies. The latter may act as a deterrent for public sector non-profit research on these resources at the expense of potentially promising (but risky) research projects that could provide widely distributed benefits in the long-term. In addition, with the exception of some basic molecular techniques, the technology necessary for accessing the deep sea and studying and isolating marine organisms is owned and operated by research institutions in very few countries. ${ }^{105}$

Thus, many countries could benefit from implementing patent subject matter exclusions as well as the exceptions and limitations to patent rights that are allowed under the TRIPs Agreement. ${ }^{106}$ This article has argued, on the one hand, that the use of MGRs and associated knowledge can be usefully promoted through the above legal flexibilities. On the other hand, countries with more advanced biotechnology capacity may decide to provide patent protection to inventions that embody new human-made constructs that are different from their naturally occurring counterparts. ${ }^{107}$ However, the management of IP assets (arising from marine scientific research) under a regime of confidentiality or trade secrecy could contradict the UNCLOS requirement to publish and disseminate MSR-related information and knowledge. By contrast, the patent literature may help in disclosing knowledge on technologies and processes, which can be in the public domain in many jurisdictions (ie other than those where patent protection was granted). Thus, the digitization of documents concerning national patent applications, their translation into different languages and their dissemination through publicly available databases could enhance access to knowledge relevant for the utilization of MGRs. Furthermore, the application of open access to research and data and open-source licensing of MGR-based inventions might hold potential for promoting benefit sharing. Instead, investment incentives arising from traditional copyright

104. Tallash Kantai, Elisa Morgera, Delia Paul and Elsa Tsioumani, 'Summary and Analysis of the Third Meeting of the Open-ended Ad Hoc Intergovernmental Committee for the Nagoya Protocol on Access to Genetic Resources and the Fair and Equitable Sharing of Benefits Arising from their Utilization (ICNP 3)', Earth Negotiations Bulletin (IISD 2014), 13, available at: $<$ http://www.iisd.ca/download/pdf/enb09617e.pdf>.

105. Arnaud-Haond et al., supra n 25.

106. Correa, supra n 30.

107. Vierros et al., supra n 28. 
approaches appear to play a decreasing role in promoting the generation of knowledge in the field of marine scientific research.

Finally, the routine disclosure, including in patent applications, of the geographic coordinates of sample collection locations could provide greater legal certainty for all those concerned with marine scientific research. Geo-referencing is already standard good scientific practice in this sector. However, the metadata that contains such information is often fragmented, making it difficult to establish whether a given MGR was collected within national jurisdiction or in ABNJ. Therefore, such information should follow all samples of the material and their sequence data throughout the chain of utilization, including for materials in $e x$-situ collections (for instance, by using unique identifier numbers). This approach would also promote synergies and provide complementarities with the Nagoya Protocol and its monitoring mechanisms. ${ }^{108}$

108. Nagoya Protocol Article 17. 